\title{
CONSTRUCTION AND TESTING OF GLUED LAMINATED TIMBER FRAMES FOR USE IN LAYING POULTRY HOUSES
}

\author{
Eduardo H. Stringari ${ }^{1 *}$, Alfredo Petrauski ${ }^{1}$, Sandra M. C. Petrauski ${ }^{1}$, Ricardo L. Azevedo ${ }^{1}$, \\ Gustavo Savaris ${ }^{2}$
}

${ }^{1 *}$ Corresponding author. UNIOESTE - Universidade Estadual do Oeste do Paraná/ Cascavel - PR, Brasil.
E-mail: stringari.eduardo@hotmail.com | ORCID: https://orcid.org/0000-0001-6708-5078

\section{KEYWORDS}

timber structure, rural buildings, adhesives, Araucaria angustifolia.

\begin{abstract}
This study aimed to present a solution in glued laminated timber to replace frame structures built in reinforced concrete and metallic structure, which are common in agricultural buildings in western Paraná such as those destined to laying poultry house building by agricultural cooperatives. Structural behavior of frames build from Araucaria angustifolia glued boards and vegetable oil-based polyurethane adhesive was evaluated. Tests were carried out to characterize wood and adhesive to obtain verification/sizing parameters. Initially, a full-scale structural project was conducted to meet standard laying poultry house specifications. Afterwards, five units of straight three-articulated frames on a 1:2.5 reduced scale were designed, built, and subjected to strength tests until breaking. They were built with a 2 -meter free span and a $15^{\circ}$ slope, suitable for using metal roof tiles. The average for structure ultimate strength was 4.14 times the design load. Structures had satisfactory mechanical performance and displacements lower than those recommended by NBR 7190 (1997) standard (ABNT). Therefore, building glued frames with Parana pine boards and vegetable oil-based glue is technically feasible.
\end{abstract}

\section{INTRODUCTION}

Construction has wide participation among economic activities using natural resources. Steel, concrete, and wood are some of the most used materials. Wood stands out as being a resource with the lowest carbon emission and artificial energy consumption (Silva et al., 2015; Techio et al., 2016; Paiva Filho et al., 2018).

Wood is a material suitable for application in rural structures because it is easy to obtain, with various application possibilities and excellent structural performance. However, wood has lost space in the market for other materials because of its technically unskilled use and growing demand for larger spans and more slender structures (Vechi \& Magalhães Júnior, 2018; FONTE, 2007).

After technological improvement combined with industrialization process, wood began to be benefited so that its shortcomings would be mitigated and its qualities enhanced. In this context, glued laminated timber (GLT) has arisen, which is a wood product formed by wooden boards glued together with different types of adhesives (Segundinho et al., 2017; Terezo et al., 2019).
GLT is an industrial product that consists of one of the ways of using wood, which has been studied in Brazil for some years (Calil Neto et al., 2016). It consists mainly of wooden boards joined together longitudinally by adhesives. Adhesive use increases the possibility of GLT use in building structures, as it does not limit geometric configurations of pieces (Fiorelli \& Dias, 2006; Segundinho et al., 2013).

Reforestation woods can be used in GLT manufacturing, mainly due to their homogeneity and sustainability, which is demanded by the consumer market. Allied to this, the use of vegetable oil-based adhesives can be highlighted as another sustainable material for being biodegradable (Calil Neto, 2014).

When sizing glued timber structures, joints must have predictable behaviors and high strength levels to meet standards and requirements of each project. Moreover, conditions under which adhesive may have its performance optimized or bonding cannot be carried out must be known to avoid losing structure strength and/or durability (Couri Petrauski et al., 2016; Molina et al.,

\footnotetext{
${ }^{1}$ UNIOESTE - Universidade Estadual do Oeste do Paraná/ Cascavel - PR, Brasil.

${ }^{2}$ UTFPR - Universidade Tecnológica Federal do Paraná/ Toledo - PR, Brasil.
} 
2016). However, not all these procedures are described in the NBR 7190 (1997) standard (Brazilian Standards). For this reason, some experimental phases were carried out according to international standards or based on research in the area.

According to Iwakiri et al. (2010), adhesion between wood and adhesives can be measured by strength tests of glued joints and percentage of failure in the wood, determined through standards. According to Molleken et al. (2016), most of the strength tests of glued joints have been designed to simulate the worst conditions of structure use and environmental conditions of transport and packaging.

Couri Petrauski (1999) built and tested GLT trussed frames of Eucalyptus citriodora and E. grandis for roofing structures with ceramic tiles, with seven meters of free span and eaves of 0.5 meters at each end. These structures had an average ratio between breaking and design loads of the order of 7.3. Moreover, a linear behavior was obtained for load x displacement diagrams, with satisfactory spans, attesting the feasibility of the proposed sizing model for glued binding.

Petrauski (2000) built roof truss made of glued laminated timber of $E$. grandis, with bindings made exclusively using adhesive, and subjected them to load tests. This author proposed a model for analyzing and sizing such bindings considering Hankinson's model to be valid due to the need to glue boards at different angles. Results were satisfactory regarding strength and stiffness performances. Their ultimate strengths were, on average, 4.26 times the design load.

Couri Petrauski et al. (2016) evaluated structural behavior of GLT frames using Eucalyptus sp. wood and two adhesives: castor oil-based polyurethane and resorcinol-formaldehyde. Five full-scale units of straight three-articulated frames, with a 5-meter free span, $48 \%$ slope, and suitable for ceramic covering, were designed, built, and subjected to load tests. Performance results of glued joints met standardized criteria and can be used in building structural joints. The averages for structure ultimate strengths, obtained using resorcinol formaldehyde and castor oil-based adhesives, were 4.63 and 4.42, respectively, showing satisfactory mechanical performance and displacements below those allowed by regulations.

Similar frames, built with the same technique suggested by Couri Petrauski et al. (2016) and designed for use in laying poultry houses, were evaluated in this research. Parana pine from reforestation was also used, and changes in inertia were considered in the roof beams, aiming at saving wood.

\section{MATERIAL AND METHODS}

This research was carried out at the Laboratory of Technology and Timber Structures (LATEM), in the University of State of West of Parana (UNIOESTE), Campus of Cascavel - PR (Brazil). The main materials used in the experiment were Araucaria angustifolia wood from reforestation, aged 30 years, and a commercial bi-component vegetable oil-based adhesive named Kehlfix-duo.

Wood was characterized according to normative prescriptions. But, given the obtaining of wood boards, normative specimens were made glued from the available material.

Adhesion properties were characterized based on ASTM D905 (1994), while the method for sizing glued bindings was based on the proposal of Petrauski (2000). Such characterization was carried out by the following tests:

- characteristic shear strength in compression of glued joints with parallel and perpendicular fibers $\left(\mathrm{f}_{\mathrm{v} 0, \mathrm{k}}\right.$ and $\left.\mathrm{f}_{\mathrm{v} 90, \mathrm{k}}\right)$.

- characteristic shear strength in torsion of glued joints with parallel and perpendicular fibers $\left(f_{\mathrm{vt} 0, \mathrm{k}}\right.$ and $\mathrm{f}_{\mathrm{vt} 90, \mathrm{k}}$ ).

Figure 1 shows the scheme of specimens used for torsion testing on the glue line. The highlighted circular region (glued surface) is subjected to a torsional stress, allowing calculating the shear strength at breaking by applying a specific formula to the strength of materials (Couri Petrauski et al., 2016).

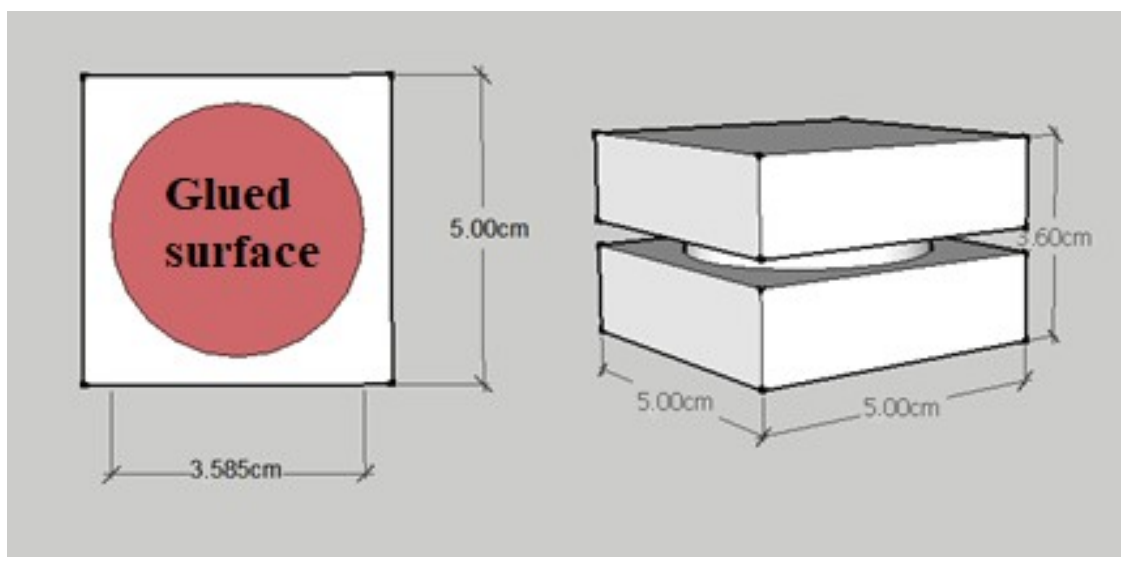

FIGURE 1. Specimen for testing of torsional shear strength.

\section{Full-scale frame}

This research proposed the replacement of mixed steel-concrete structures under construction in the west of Paraná, as shown in Figure 2A, with a three-articulated GLT frame model shown in Figure 2B. It was designed for roofing using metal tiles, $15^{\circ}$ slope, eaves of 1 meter, and spacing between frames of 2.50 meters. Figure $2 \mathrm{~B}$ shows the sections of the boards that would compose the full-scale structure if it were executed, with the required verification. 
A

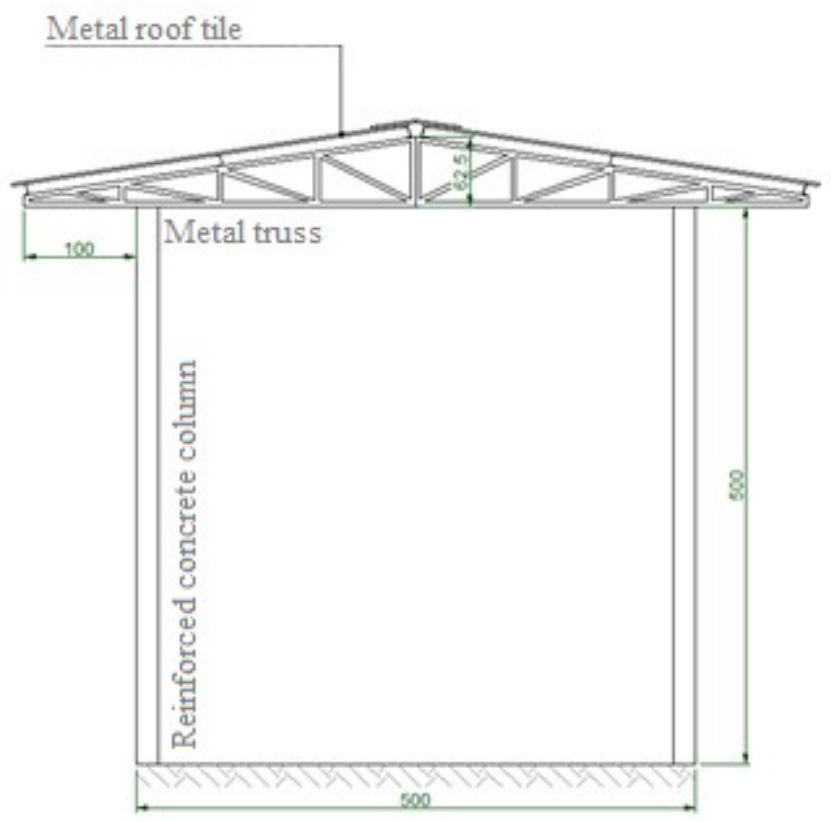

B

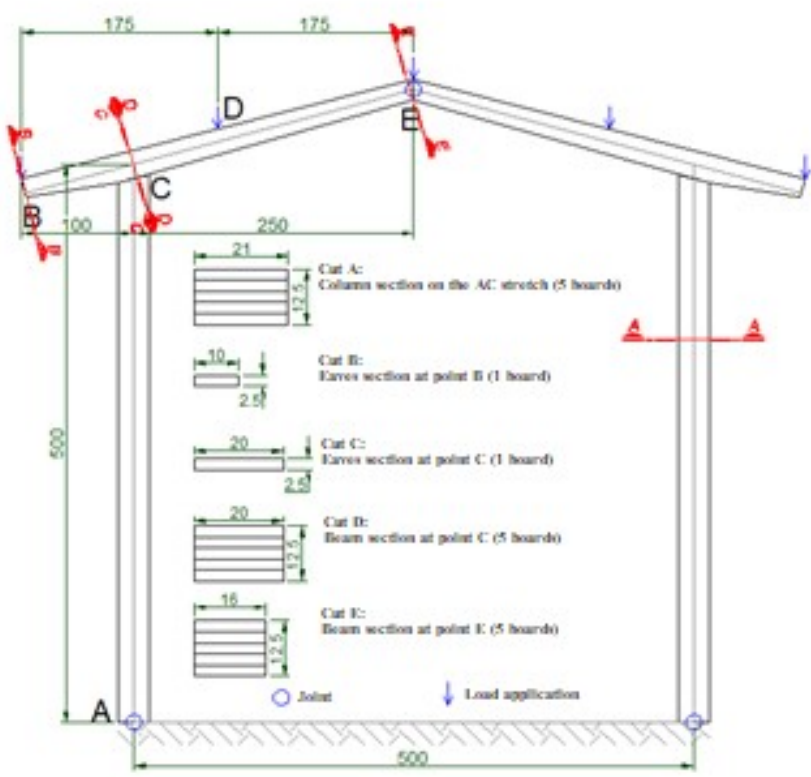

FIGURE 2. (A) General scheme of a laying poultry house geometry by the Lar Agricultural cooperative and (B) general configuration of the full-scale frame (Unit: $\mathrm{cm}$ ).

Nodes $\mathrm{A}$ and $\mathrm{E}$ showed in Figure 2B are joints, and node $\mathrm{C}$ is a rigid binding, i.e., it must withstand bending moment $(\mathrm{Md})$, normal strength $(\mathrm{Nd})$, and shear strength (Qd) acting on this binding. The use of a joint at E, considering an industrial design, aims to facilitate the transport of parts to the assembly site.

Lifting of loads due to wind was made according to standard NBR 6123 (1988), using the free program VISUALVENTOS (http://www.etools.upf.br, 2008), developed by the University of Passo Fundo, RS, Brazil. In this case, a rural building in the region of Cascavel, PR, Brazil, in open terrain and with few obstructions was considered.

A vertical overload of $1 \mathrm{kN}$ was adopted, as suggested by standard NBR 6120 (1987). In terms of calculation approaches, we followed the NBR 7190 (1997) standard for combinations of actions. Finally, the distance limit between supports (span) followed criteria foreseen in the Brazilian standard for common structures. Then, once it is a rural construction, a limit equal to $\mathrm{L} / 200$ was adopted.

The frame was checked for the most severe combinations from two hypotheses: overpressure or wind suction. However, the suction hypothesis predominated. In this sense, the state of a more severe effect of stresses was equivalent to the stresses indicated in Figure 3. In addition, wind action, as illustrated, was adequately located on purlins for implementation in the program Ftool of PUC/RJ (www.ftool.com.br, 2012).
A

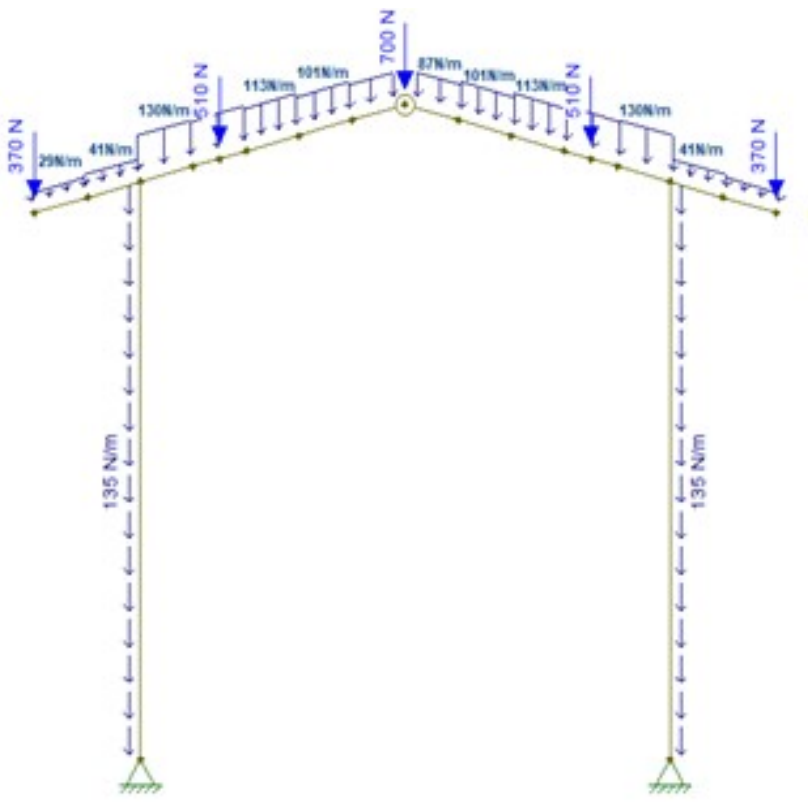

B

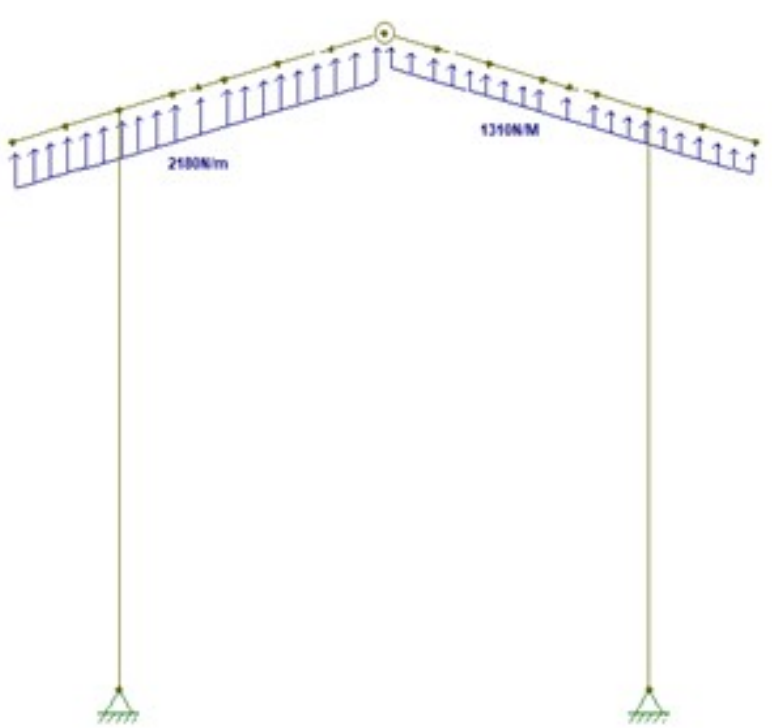

FIGURE 3. (A) Permanent action on the structure, and (B) wind suction, according to VISUALVENTOS. 
In this research, a solution would allow imposing a variation of inertia on the roof bars was sought to reduce the section in less requested regions. It included a solution that aims to design with less material consumption.

The use of five wood boards of $2.5 \mathrm{~cm}$ thick was considered for piece composition, and the final sections are shown in Figure 2B. The critical region, which guided the solutions, was the rigid binding at node $\mathrm{C}$. Two boards coming from the column, joined by adhesive to another three boards that form the cover, were used to resist stresses applied to this binding. These sets of boards were verified for bending, bending-compression, and shear, as appropriate. Additionally, a criterion was applied to verify the glued surfaces.

Column-beam binding requires bonding with a slope other than $0^{\circ}$, which is not included in the standard NBR 7190 (1997). For this reason, the methodology proposed by Petrauski (2000) and Couri Petrauski et al. (2016) was used, allowing the quantification of a necessary bonding area to face the active stresses $\mathrm{Md}, \mathrm{Qd}$, and $\mathrm{Nd}$ through the glued areas $\mathrm{AM}, \mathrm{AQ}$, and $\mathrm{AN}$.

Except for this verification, i.e., the rigid bonded region, all other verifications are those standardized and prescribed by NBR 7190 (1997). Finally, spans were evaluated using the mildest criterion of the Brazilian norm since it is a rural building.

\section{Reduced scale frame}

A reduced scale was adopted for the structure of tests because of the geometric limitation of the reaction frame of UNIOESTE/Cascavel, PR, Brazil. Therefore, the reduced-scale project considered that the real geometry would be reduced on a scale of $1: 2.5$. The idea of carrying out the main bars of the frame (column and roof beam), with five boards each, was maintained.

A thickness equal to $1.5 \mathrm{~cm}$ was adopted for all boards to reduce the waste of material, as they were acquired with a thickness of $2.5 \mathrm{~cm}$. In addition, a $1 \mathrm{~cm}$ board could cause processing problems in the available machinery.

Moreover, load application devices available in the laboratory would prevent the reproduction of the solution found for the full-scale frame, which was obtained by the hypothesis of wind suction. Therefore, a way to reproduce the loading with inversion of the direction of load application needed to be developed.

We sought to obtain a workable load (top-to-bottom forces) that would generate the same influence on a reduced frame, for bending moments at rigid nodes, and that was associated with the critical request of a real frame. Critical bending moment stresses in the real frame design can be seen to the left of Figure 4, while to the right, the equivalent for the reduced frame is shown. Real frame critical situation is equivalent to bending moments that pull the internal fibers at $\mathrm{C}$. As this type of stress could not take place in the reduced frame, we sought a solution encompassing a percentage of these moments, but pulling the external fibers at C. As shown in Figure 4A, only $17 \%$ of the values of the moments acting on the real structure were used in the reduced frame.
A

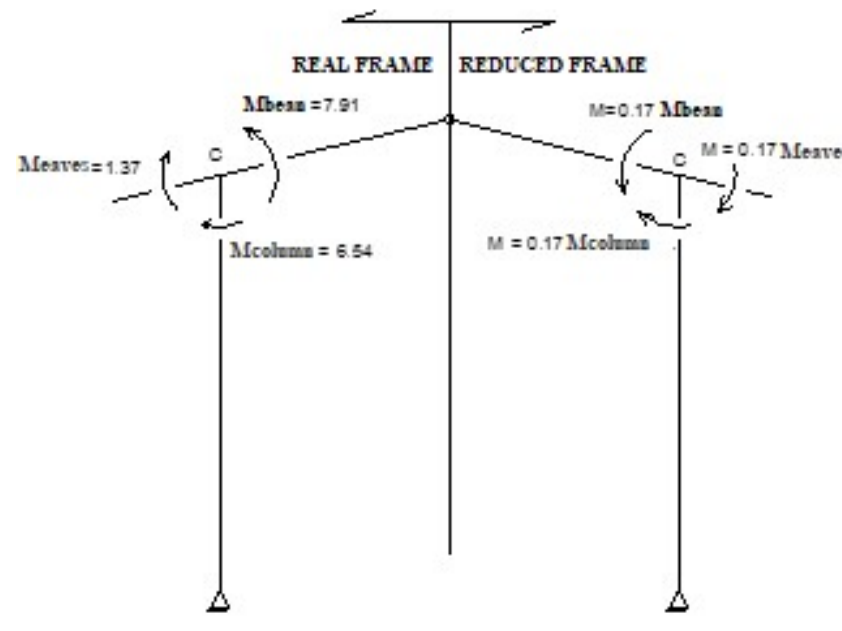

B

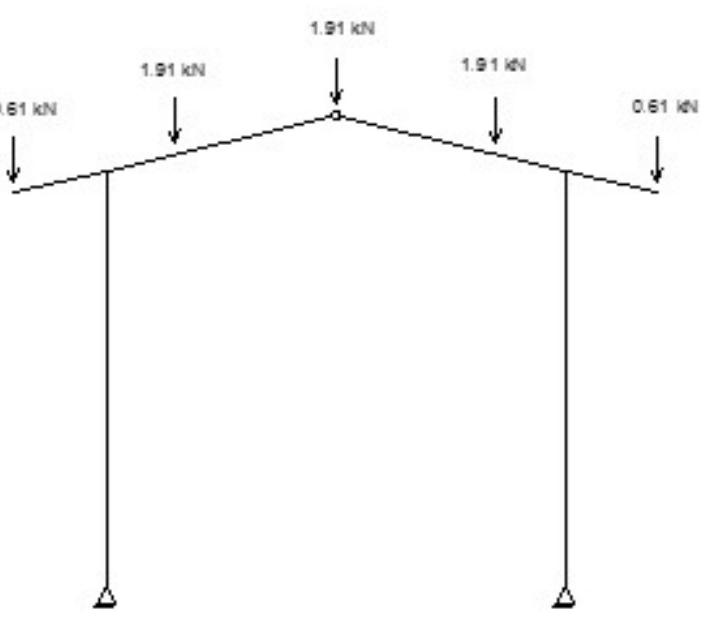

FIGURE 4. (A) Comparison of stresses at node $\mathrm{C}$ of the real and reduced frames and (B) design load of the reduced frame (Unit: $\mathrm{kNm})$.

The analysis showed that the loading state shown in Figure $4 \mathrm{~B}$ would impose the desired stress state on the rigid binding of the reduced frame.

A structural analysis was carried out based on the design load of the reduced frame to obtain the stresses at different points of the structure. Figure 5 shows the geometric configuration chosen for the reduced structure in glued laminated timber, emphasizing the sections of boards that made up the structure.

A solution compatible with that obtained for the full-scale frame was sought for the reduced-scale frame in the region of node $\mathrm{C}$. This compatibility fulfilled two aspects: wood boards under limit situations of bending strength and glued surfaces with shear stresses with values close to those found for the structure on real scale. 


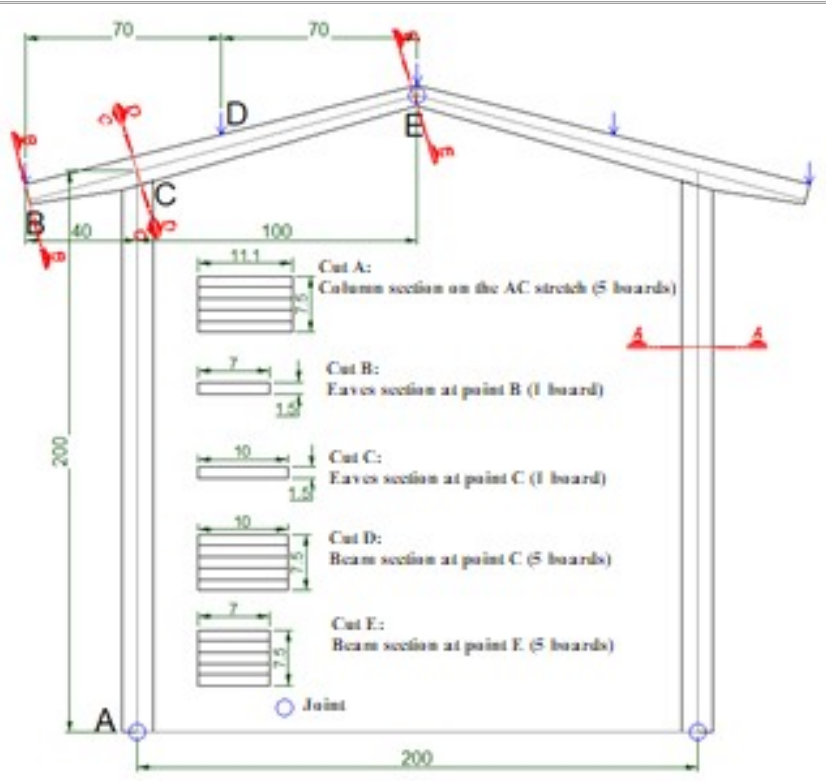

FIGURE 5. General configuration of the reduced-scale frame (Unit: $\mathrm{cm}$ ).

\section{Execution of structures}

Five reduced-scale frames were executed, being Frame 1 with less dense wood, Frame 2 with more dense wood, and Frames 3, 4, and 5 with medium density wood. In the distribution of densities, pieces were separated to allow the symmetrical sides of the same frame to have similar values.

In the first phase, the boards were prepared for bonding using the laboratory machinery. Two templates were made for bonding the frames, aiming at providing the accommodation for pieces in their position and, mainly, the application of the necessary load for the adequate bonding pressure.

The required adhesive was prepared for all layers before bonding, considering the consumption of $300 \mathrm{~g} / \mathrm{m}^{2}$. This total was separated into four containers, one for each layer. It was followed by the application of the adhesive to the wood surface, spreading it with a brush, positioning the boards, and repeating the operation until the last layer. For the adhesive, the ratio between the isocyanate and polyol components was $1: 1.5(\mathrm{w} / \mathrm{w})$

After applying the adhesive and positioning the boards, there was a period for their accommodation and, then, pressing began. The pressure was exerted by tightening a set of threaded bars fixed to the template. Tightening control was performed with a spanner equipped with a strain gauge, and reading made on a previously calibrated datalogger. The used pressure was $1.1 \mathrm{MPa}$. The closed assembly time was 25 minutes, and the open assembly time was zero. Wood had an average moisture content of $12.07 \%$ at the bonding procedure.
The structure was under pressure in the template for a minimum of 12 hours after the bonding procedure. A minimum period of 7 days was waited for the tests to be carried out.

\section{Test of built structures}

Each frame was tested individually in the reaction frame. The strength application system consisted of hydraulic cylinders used to apply vertical loads to the beams of the frame hoofing. Trays were made for load application at the eaves using concrete ballasts. Two load cells were installed in two cylinders arranged on the beams to monitor and record strengths.

Hinge supports were made using wood to connect the frames at the base, ensuring the design conditions. These supports were fixed to the reaction frame at the laboratory. The lateral containment system was made using metallic bearings, allowing free movement of the structure in the directions of its deformed state. This containment system aimed to simulate theoretical bracing and allowed free movement in the load direction but preventing displacements outside the structure surface and accidents when a breaking occurs.

Six dial indicators were installed at pre-established points to read frame displacements under load. The points considered were those that presented the highest displacements in the simulation carried out in the Ftool program (www.ftool.com.br).

The general installation scheme of the apparatus used for the tests is shown in Figure 6. 


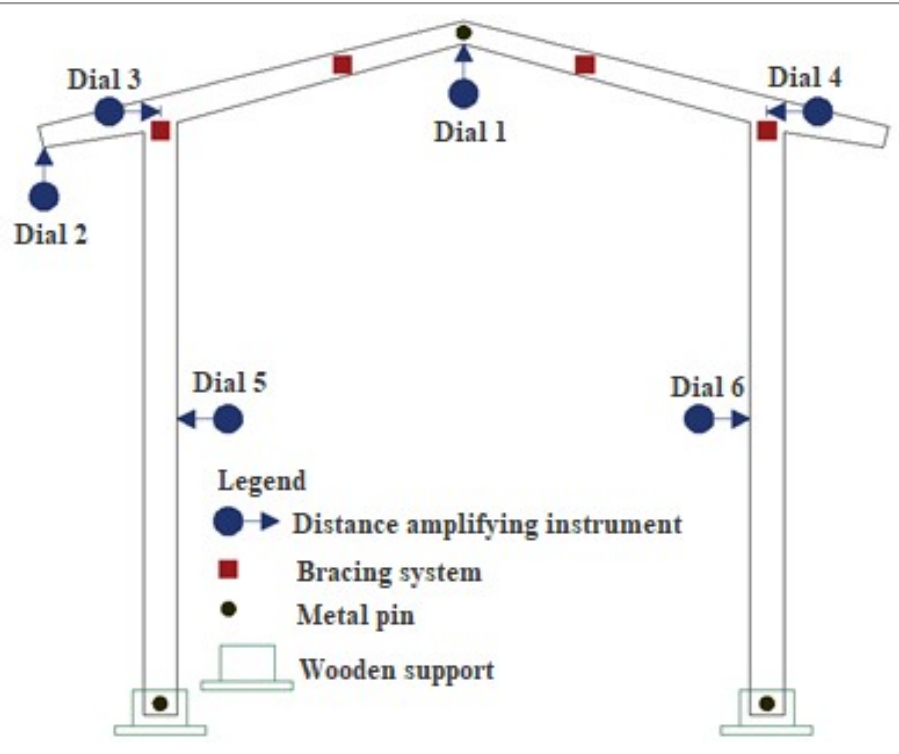

FIGURE 6. Assembly scheme of the testing apparatus.

Initially, a load was applied to the structure up to a level corresponding to the design load, including the eaves load, and displacements were recorded. Then, a second loading was applied, but with no load on the eaves. Displacements were read at each level of load application up to a safe value so as not to damage the dial indicators or put in danger those present. Finally, the dial indicators were removed, a load was applied until the failure of the tested structure, and the last load recorded by the load cell reading equipment was recorded.

\section{RESULTS AND DISCUSSION}

The result of wood characterization is shown in Table 1.

TABLE 1. Results of wood mechanical characterization corrected for $12 \%$ moisture.

\begin{tabular}{ccccc}
\hline Property & Number of specimens & Characteristic value $(\mathrm{MPa})$ & Mean $(\mathrm{MPa})$ & Standard deviation $(\mathrm{MPa})(\mathrm{CV}(\%))$ \\
\hline $\mathrm{f}_{\mathrm{c} 0, \mathrm{k}}$ & 22 & 45.8 & 52.6 & $6.8(12.93)$ \\
$\mathrm{E}_{\mathrm{c} 0, \mathrm{~m}}$ & 22 & - & 15904 & $2369(14.90)$ \\
$\mathrm{f}_{\mathrm{v} 0, \mathrm{k}}$ & 22 & 8.8 & 10.53 & $1.88(17.85)$ \\
\hline
\end{tabular}

Source: The author (2018).

Characterization of wood adhesion properties with the two-component adhesive adopted in this research is shown in Table 2.

TABLE 2. Average adhesion properties of Araucaria angustifolia wood glued with a two-component vegetable oil-based adhesive.

\begin{tabular}{ccccc}
\hline \multirow{2}{*}{ Test } & \multirow{2}{*}{ Angle $\left(^{\circ}\right)$} & \multicolumn{2}{c}{ Strength (MPa) (CV\%) } \\
\cline { 3 - 5 } & 0 & No. of CP & Strength & Standard deviation \\
\hline $\mathrm{f}_{\mathrm{v} 0}$ & 90 & 24 & 10.99 & $1.37(12.46)$ \\
$\mathrm{f}_{\mathrm{v} 90}$ & 0 & 34 & 4.09 & $1.02(24.94)$ \\
$\mathrm{t}_{\mathrm{v} 0}$ & 90 & 24 & 10.60 & $2.16(20.38)$ \\
$\mathrm{t}_{\mathrm{v} t 90}$ & & & 8.51 & $1.94(22.8)$ \\
\hline
\end{tabular}

All frames were tested until breaking to determine structure strength. Table 3 shows a summary of the information related to the strength of each frame.

TABLE 3. Performance of the tested structures in terms of strength.

\begin{tabular}{cccccc}
\hline Frame & $\begin{array}{c}\text { Mass } \\
(\mathbf{k g})\end{array}$ & Breaking site & $\begin{array}{c}\text { Breaking load } \\
(\mathbf{k N})\end{array}$ & $\begin{array}{c}\text { Design load (kN) } \\
\text { Frame 01 }\end{array}$ & $\begin{array}{c}\text { Ratio between breaking load } \\
\text { and design load }\end{array}$ \\
\hline Frame 02 & 37.2 & Nodes C and E & 25.21 & 6.946 & 3.63 \\
Frame 03 & 29.2 & Nodes C and E & 34.60 & 6.946 & 4.98 \\
Frame 04 & 29.5 & Node C & 24.37 & 6.946 & 3.51 \\
Frame 05 & 29.7 & Nodes C and E & 31.24 & 6.946 & 4.50 \\
\hline Mean & 29.48 & Node C & 28.52 & 6.946 & 4.11 \\
\hline
\end{tabular}


It is difficult to say whether the first breaking started at the rigid glued binding site or at the ridge only analyzing the data shown in Table 3. It occurs because breaking is sudden and presents an immediate release of accumulated energy at the final instant of collapse. However, all five structures showed breaking on at least one side and the rigid binding (node C).

The design load, including loads at the eaves using ballast trays, was applied in the first phase of individual tests. An increase of less than $10 \%$ was observed in the final applied loads compared to the project due to experimental conditions. In this phase, for safety reasons, the final load applied was in the order of $7.586 \mathrm{kN}$. The average displacements shown in Table 4 were found for the design load.

The displacements in the frame test had results similar to those found in computer simulations carried out using the program Ftool. Figure 7 shows the obtained averages of deformed configuration and those estimated by the program. In general, the values are very similar.

TABLE 4. Final average displacements after applying a load of $7.586 \mathrm{kN}$.

\begin{tabular}{ccccc}
\hline Test structure & Dial 1 (mm) & Dial 2 (mm) & $\begin{array}{c}\text { Dial 3 and 4 } \\
\text { Mean }(\mathbf{m m})\end{array}$ & $\begin{array}{c}\text { Dial 5 and 6 } \\
\text { Mean }(\mathbf{m m})\end{array}$ \\
\hline Test 01-P1 & 7.29 & 1.46 & 2.20 & 2.34 \\
Test 02-P2 & 6.52 & 1.15 & 1.85 & 2.61 \\
Test 03-P3 & 6.78 & 1.26 & 1.94 & 2.61 \\
Test 04-P4 & 7.14 & 1.15 & 2.14 & 2.94 \\
Test 05-P5 & 6.78 & 1.07 & 1.56 & 2.44 \\
Mean & 6.90 & 1.22 & 1.94 & 2.59 \\
\hline
\end{tabular}

Figure 7 shows that the results estimated by the Ftool were higher than the experimental results, except for the eaves. It occurred because abrupt losses of inertia were implemented in the Ftool, but it was actually gradual. The results obtained in this phase indicated a linear behavior in the force-displacement diagram, as shown in Figure 8.

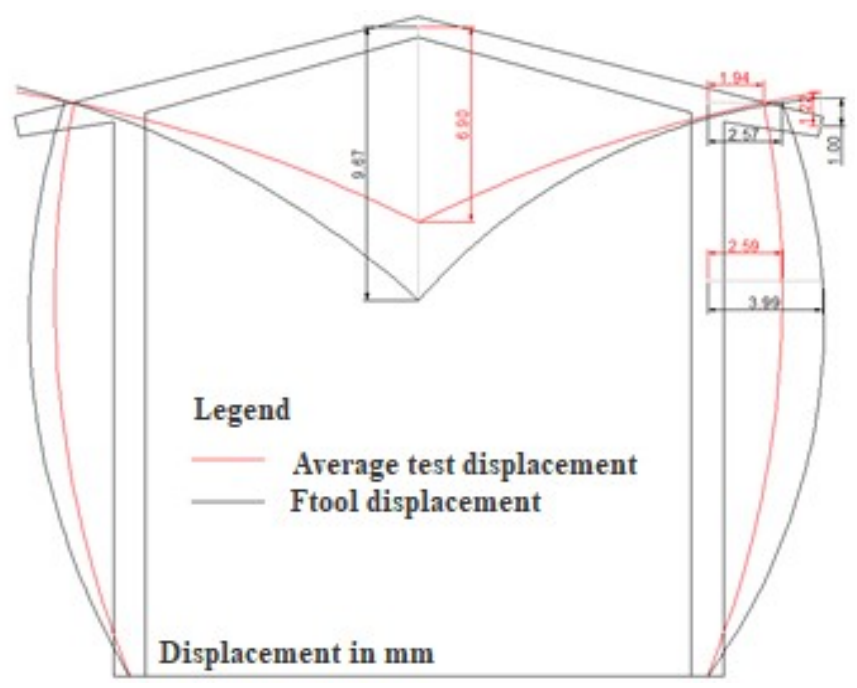

FIGURE 7. Comparison between the average test displacement and the deformation in the Ftool for a total load of $7.586 \mathrm{kN}$. 
A

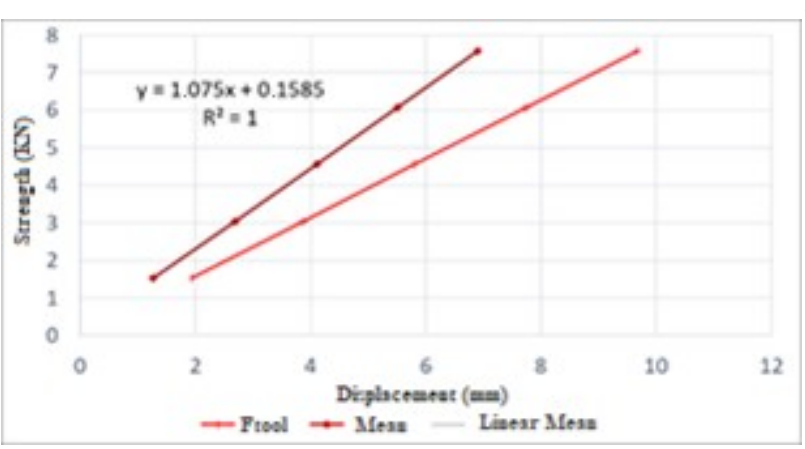

C

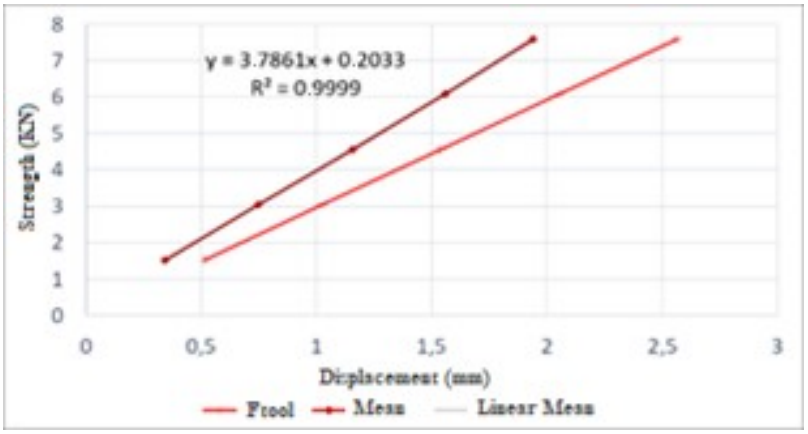

B

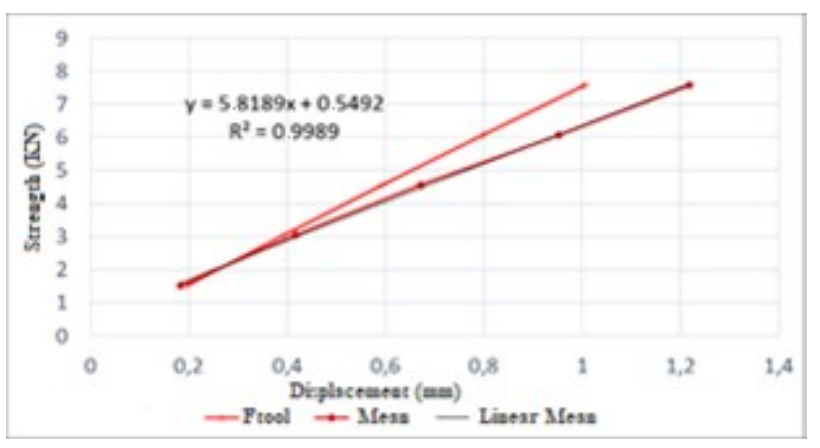

$\mathrm{D}$

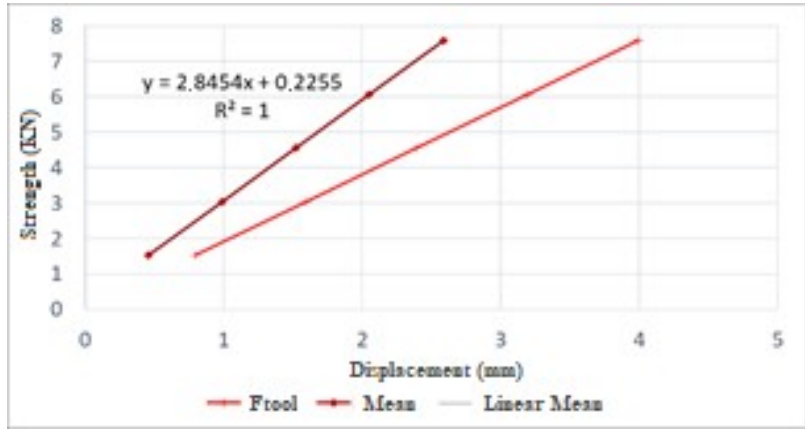

FIGURE 8. Means of load-displacement diagram. (A) Dial indicator 1 - ridge, (B) dial indicator 2 - eaves, (C) dial indicator 3 - binding $\mathrm{C}$, and (D) dial indicator 4 - column span.

After applying the design load, the load of trays on the eaves was removed, and all the load applied to the frame was zeroed, then a new test phase was started by applying vertical loads until breaking the structures. The results obtained in this phase also indicated a linear behavior in the force-displacement diagram. On average, on the ridge structures reached a span limit of only $10 \mathrm{~mm}$ for values of about 1.2 times the design load. Figure 9 shows the phases of execution, testing, and breaking of structures.

A

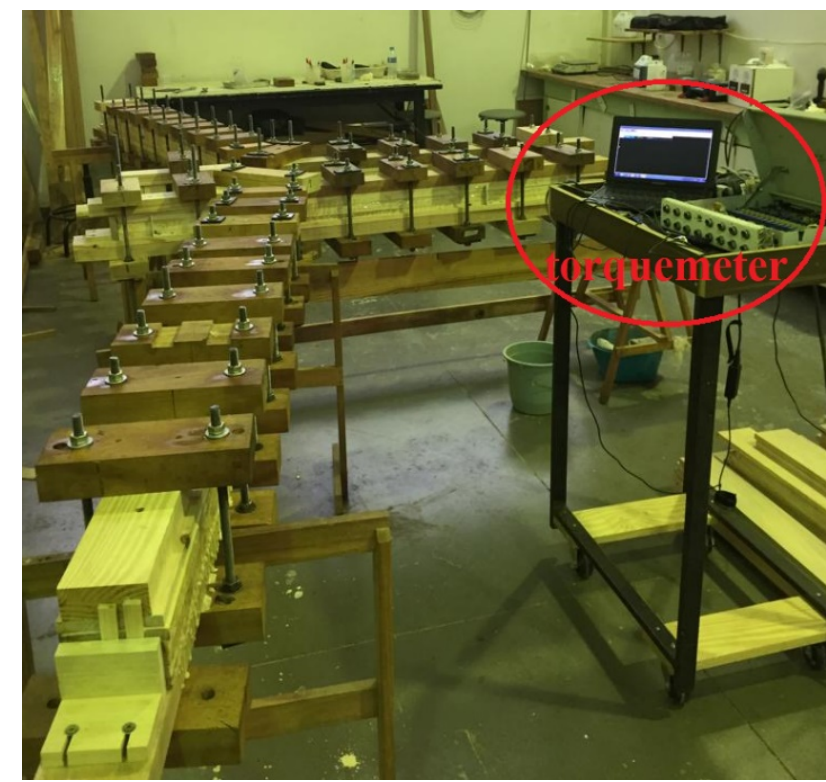

B

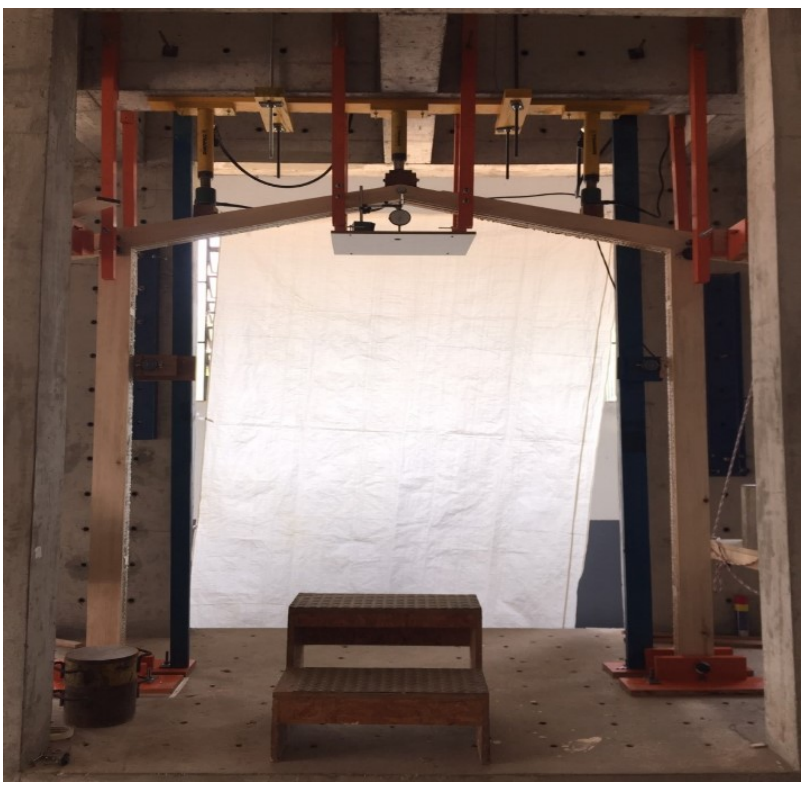


$\mathrm{C}$

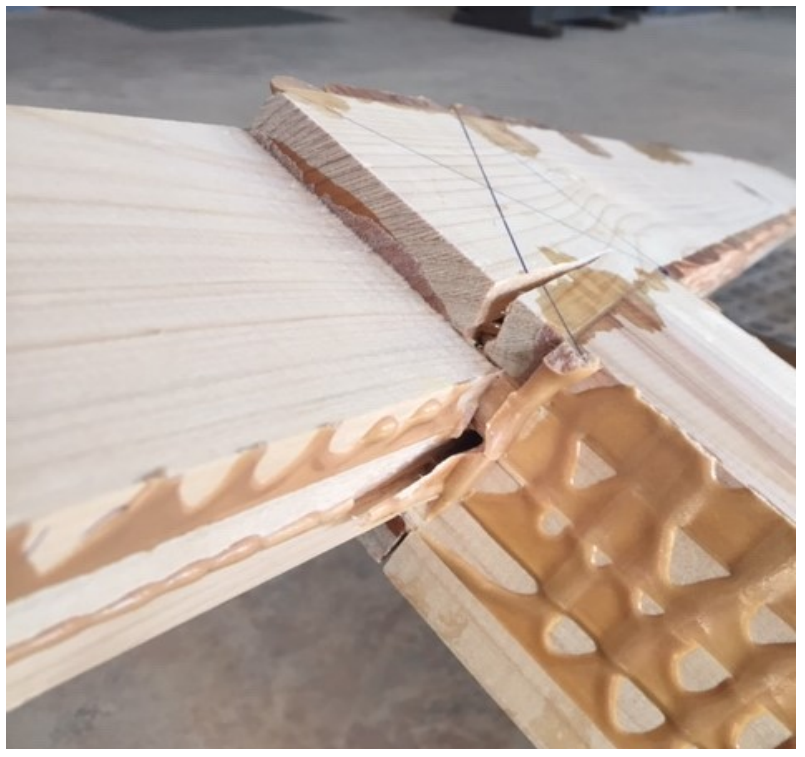

$\mathrm{D}$

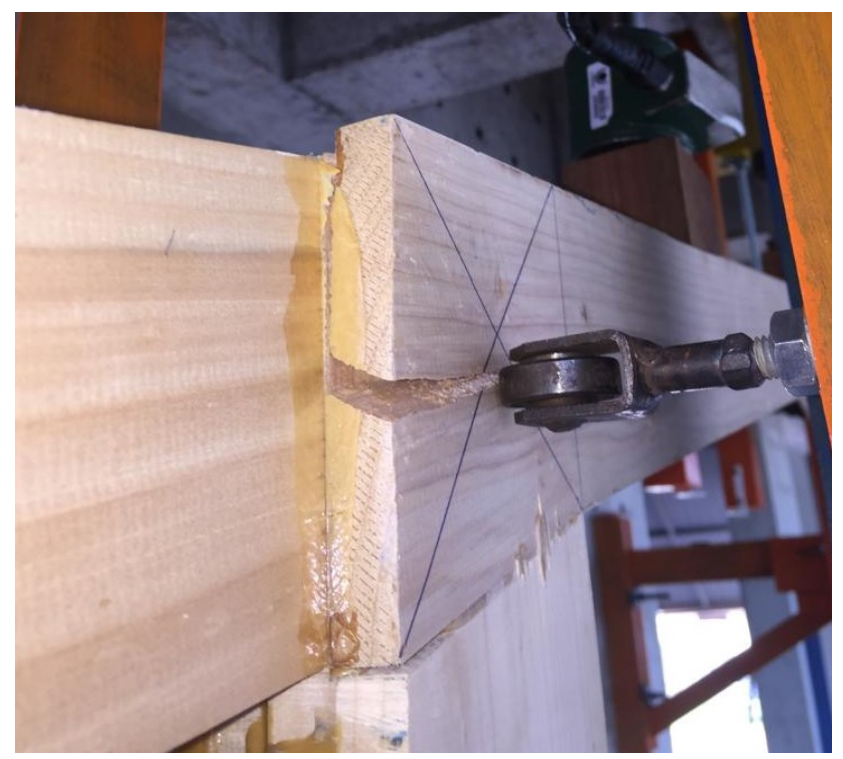

FIGURE 9. Experimental phases: (A) Execution of a frame in the template, (B) frame installed in the test apparatus, (C) example of breaking in region $\mathrm{C}$, and (D) example of breaking in region $\mathrm{C}$.

The studies conducted by Petrauski (2000) and Couri Petrauski et al. (2016) showed that models of structures similar to the frames tested in our research, with glued timber bindings, are feasible and have a satisfactory behavior.

The ratio between breaking and design loads indicates structure safety, with an average of 4.14. This ratio can be considered very satisfactory when compared, for example, with results obtained in tests of similar structures (Petrauski, 2000; Couri Petrauski et al., 2016).

The linear behavior of displacements of fully bonded structures has already been observed by Couri Petrauski et al. (2016) and Petrauski (2000). In this case, glued laminated timber frames built with Araucaria angustifolia and vegetable oil-based glue had a good performance in terms of strength and stiffness, even for the highest load levels.

\section{CONCLUSIONS}

From the observed data, the methodology used to verify the structure, especially in the region of the rigid binding, was adequate for the proposal. Therefore, within a controlled process, these materials can produce structures with satisfactory bindings in terms of strength and stiffness performance.

Frame performance was satisfactory, considering the strength criteria. Breakings occurred, as expected, in the rigid bindings, as they were the place of highest stresses and, in the design phase, led to the sizing/verifications.

The proposed technique for building frames seems to be a good option to be used in practice in the laying poultry house, with good safety levels and structural reliability.

\section{REFERENCES}

ABNT - Associação Brasileira de Normas Técnicas (1980) NBR 6120 - Cargas para o cálculo de estruturas de edificações. Rio de Janeiro, $5 \mathrm{p}$.
ABNT - Associação Brasileira de Normas Técnicas (1988) NBR 6123 - Forças devidas ao vento em edificações. Rio de Janeiro, 66p.

ABNT - Associação Brasileira de Normas Técnicas (1997) NBR 7190 - Projeto de estruturas de madeira. Rio de Janeiro, 107p.

American Society for Testing and Materials (1994) D-905: Annual book of A.S.T.M. Philadelphia, 478p. (Standards, 15.06, Adhesives).

Calil Neto C, Christoforo AL, Ribeiro Filho SLM, Lahr FAR, Calil Junior C (2014) Avaliação da resistência ao cisalhamento e à delaminação em madeira laminada colada. Ciência Florestal 24(4):989-996. Available: http://www.scielo.br/scielo.php?script=sci_arttext\&pid=S1 980-50982014000400989\&lng=pt\&nrm=iso.

Calil Neto C, Molina JC, Calil Junior C, Lahr FAR (2016) Specie - treatment - adhesive combinations for glulam purpose. Revista de Engenharia Civil IMED 3(2):16-23. DOI: https://doi.org/10.18256/2358-6508/recimed.v3n2p16-23

Couri Petrauski SMF (1999) Desenvolvimento e teste de pórticos treliçados feitos de madeira de Eucalyptus citriodora e Eucalyptus grandis laminada e colada. Dissertação Mestrado em Ciência Florestal, Viçosa, Universidade Federal de Viçosa.

Couri Petrauski SMF, Silva JC, Petrauski A, Lucia RMD (2016) Analysis of eucalyptus glued-laminated timber porticos structural performance. Revista Árvore 40(5):931-939.

Fiorelli J, Dias AA (2006) Fiberglass-Reinforced Glulam Beams: mechanical properties and theoretical model. Materials Research 9(3):263-269. 
Iwakiri S, Matos JLM, Pinto JA, Viana LC, Souza MM, Trianoski R, Almeida VC (2010) Produção de painéis laminados unidirecionais-LVL com lâminas de Schizolobium amazonicum, Eucalyptus saligna e Pinus taeda. Cerne 16(4):557-563. DOI: https://doi.org/10.1590/S0104-77602010000400015

Molina JC, Calil Neto C, Christoforo AL (2016) Resistência à tração de emendas dentadas de madeira de Manilkara huberi para o emprego em madeira laminada colada. Ambiente Construído 16(1):221-227. DOI: http://dx.doi.org/10.1590/s1678-86212016000100070

Molleken RE, Trianoski R, Claro Neto S, Pereira CR, Iwakiri S, Azevedo EC (2016) Evaluation of pressing time in the production of edge glued panel with adhesive polyurethane derived from castor oil. Applied Adhesion Science 4:1-8.

Paiva Filho JC de, Almeida LA, Castro VG de, Diodato MA (2018) Diagnóstico do uso da madeira como material de construção no município de Mossoró-RN/Brasil. Matéria 23(3):e12179. DOI: http://dx.doi.org/10.1590/s1517-707620180003.0513

Petrauski A (2000) Comportamento de ligações adesivas e avaliação experimental de tesouras de telhados feitas de laminado colado com madeira de Eucalyptus grandis. Tese Doutorado, Viçosa, Universidade Federal de Viçosa.
Segundinho PGA, Zangiácomo AL, Carreira MR, Dias AA, Lahr FAR (2013) Avaliação de Vigas de Madeira Laminada Colada de Cedrinho (Erisma uncinatum Warm.). Cerne 19(3):441-449.

Segundinho PGA, Gonçalves FG, Gava GC, Tinti VP, Alves SD, Regazzi AJ (2017) Eficiência da colagem de madeira tratada de Eucalyptus cloeziana F. Muell para produção de madeira laminada colada (MLC). Matéria 22(2):e11808. DOI: http://dx.doi.org/10.1590/s1517707620170002.0140

Techio EM, Goncalves JP, Costa PN (2016)

Representação social da sustentabilidade na construção civil: a visão de estudantes universitários. Ambiente \& Sociedade 19(2):187-204. DOI: http://dx.doi.org/10.1590/18094422ASOC130991V1922016

Terezo RF, Cordova FO de, Sampaio CA de P (2019) Chemically treated glued laminated paricá timber (Schizolobium parahyba var. amazonicum). Engenharia Agrícola 39(2):158-165. DOI:

http://dx.doi.org/10.1590/1809-4430eng.agric.v39n2p158-165/2019

Vechi A, Magalhães Júnior CAO (2018) Aspectos positivos e negativos da cultura do eucalipto e os efeitos ambientais do seu cultivo. Valore 3(1):495-507. 